\title{
Preliminary phytochemical analysis of selected plants occurring in district Nowshera, Khyber Pakhtunkhwa
}

Sajjad Ali ${ }^{1}$, Muhammad Nauman Khan ${ }^{1 *}$, Kashif Ali ${ }^{2}$, Akhtar Zaman ${ }^{3}$ and Majid Iqbal ${ }^{4}$

1. Department of Botany, Bacha Khan University Charsadda KP-Pakistan

2. Department of Botany, Islamia College University, Peshawar, KP-Pakistan

3. Department of Botany, University of Peshawar, KP-Pakistan

4. Department of Plant Sciences, Quaid-i-Azam University, Islamabad 45320-Pakistan

*Corresponding author's email:nomiflora@uop.edu.pk

Citation

Sajjad Ali, Muhammad Nauman Khan, Kashif Ali, Akhtar Zaman and Majid Iqbal. Preliminary phytochemical analysis of selected plants occurring in district Nowshera, Khyber Pakhtunkhwa. Pure and Applied Biology. Vol. 9, Issue 1, pp683-695. http://dx.doi.org/10.19045/bspab.2020.90074

\begin{tabular}{llll}
\hline \hline Received: 01/08/2019 & Revised: 03/12/2019 & Accepted: 09/12/2019 & Online First: 26/12/2019 \\
\hline
\end{tabular}

\section{Abstract}

Plants have some chemical origin that it contains important constituents and secondary metabolites, which are responsible for growth, development and other physiological action on other living organism. The current work investigated the qualitative analysis of major bioactive constituents of 10 medicinally important plants Viz Olea ferruginea, Chenopodium murale, Plantago lanceolata, Lactuca serriola, Parthenium hysterophorus, Carthamus oxycantha, Chrozophora tinctoria, Achyranthes aspera, Withania somnifera and Cichorium intybus were collected at two growth stages from different localities of district Nowshera, KP, Pakistan for their authentication. Alkaloids, Tannins, Sugar, Saponins, Flavonoids, Terpenoids, Cardiac Glycosides, Phenolics and Anthraquinone were analyzed qualitatively in two phenological stages (vegetative and fruiting stage) in all botanical taxa at three chemical fraction (n-hexane, chloroform and methanolic fraction) for its high potency for utilization of medicinal plants. The phytochemical evaluation revealed the presence of these chemical compounds. It was concluded that diversity of methyl alcohol (Methanolic) extract were most important regarding the presence of different biochemical compounds and proved that these plants are highly medicinal and responsible for treatment of many ailments. Therefore, information on these accessions could be best utilized for its commercial scale.

Keywords: Methanolic and N-hexane fraction; Medicinal plants; Nowshera; Qualitative study Introduction

Phytochemistry or plant chemistry is concerned with the enormous variety of organic substances which are accumulated by plants. It deals with the chemical structured of these substances, their biosynthesis, turnover and metabolism, their natural distribution and biological function [1]. Medicinal plants contain some organic compounds which provide definite physiological action on the human body and these bioactive substances include tannins, alkaloids, carbohydrates, 
flavonoids, terpenoids and steroids. These chemical components of plants material are useful for care of health and take the capacity to keep the body from injurious damages. The occurrence of these chemical constituents is biologically, taxonomically and chemically very different due to large amount of its screening and useful for documentation of its aromatic characteristics [2]. Thus they are measured as secondary metabolites compounds because they are achieved from some plants origin and manufactured obviously from all parts of plants i.e. leaves, flowering tops, stem, bulbs, flowers, fruits, roots, seeds, rhizome, bark and some other parts which contains greater quantity of bioactive constituents. These chemical constituents may change from one another both quantitatively and qualitatively in diverse plants material [3]. Biological samples have phytochemicals and metabolites, omics (metabolomics) approaches are used to investigate these phytochemicals and metabolites [4]. Plants and angiosperms (subdivision of recently evolutionary flowering plants) populated majority of the terrestrial surface of earth in complex relationship with other organism and added huge contribution to the earth biomass by weight and volume in comparison with all other life form combined $[5,6]$. These stationary autotrophs plants have to face a number of challenges in their natural environment for the survivals that include the engineering of their own pollination and seed dispersal, local variation in the supply of simple nutrient required for the preparation of their own food, pathogens and herbivores presence in their surrounding environment. Therefore plant adopts pathways of secondary metabolites (Synthesis of biochemical) in response of these stimuli and environmental stress i.e. nutrient degradation, pathogens attacks and herbivores persuaded damages $[7,8]$. Specific genera and species have unique phytochemicals (Secondary metabolites) which do not perform any part in primary metabolites, but they play an important role in the general survival ability and to endure the local challenges by interacting with their surrounding environment [9]. The importance of secondary metabolites can be indicated from the consumption of the energy in their synthesis which is far greater in amount required for the preparation of primary metabolites [10]. Some of the activities of the plant are directly related with phytochemicals and straightforward i.e protective roles (UV light-absorbing, free radical-scavenging, as antioxidant and antiproliferative agents) and act as defensive agent against plant microbe such as viruses, bacteria and fungi etc. They also defend plant from allelopathic effect of competitor plant and manage inter-plant relationships. The most important and crucial function include adapting the plant's relationship with other intricate organisms [11-13]. As compared to the artificial chemical modern sophisticated drugs, the interest and usage of natural herbal medicine has been increasing because of their efficacy and less Side effects. It is a known fact that modern Western medicine contains active chemical ingredients derived from the plants $[14,15]$. It is predictable that 5000 phytochemicals have been acknowledged individually from plant species however a greater number is still remain unidentified to understand the beneficial effects of phytochemicals as its nutritional values in whole food [16]. Alkaloids, tannins, saponins, flavonoids, terpenoids carotenoids, glycosides and phenolic compounds are classified as phytochemicals. The compound having one or more than one aromatic ring with hydroxyl group (One or more than one) are categorized generally as phenolic compound. These compounds are secondary metabolism product performing various function in the plants life such as plants growth and reproduction, provide defense 
against pathogen, predators and parasite and also added their role in the photosynthetic pigments and process. In addition to these roles, it also plays a vital part in the reduction of some chronic disease $[17,18]$. Flavonoids (Phenolic compound group) is also linked with reduction of major chronic diseases found in fruits, vegetable and other plant species having antioxidant activities. Up to now the identified number of flavonoids is above than 4000. The flavonoids added roughly two third parts in diet while remaining one third is added by phenolic acids. Daily human flavonoids intake is estimated from few hundred $\mathrm{mg}$ to $650 \mathrm{mg} / \mathrm{d}$ [19-21]. The substantial attention receiving compound is carotenoid which is widespread pigment in nature because of their antioxidant roles and pro-vitamin nature. Till recent decade, 600 carotenoids of different function have been identified [22]. Human's cells and other organism's cells are continuously visible to different oxidizing agents, most of which are essential for life.

Materials and methods

\section{Collection of plant material and extract preparation}

The study was conducted to evaluate and detect various secondary metabolites for identification of medicinal plants in district Nowshera, KP, Pakistan during 2017-18 in flowering and fruiting season. The area lies in KP province of Pakistan having $33^{\circ} 42$ to $34^{\circ} 09 \mathrm{~N}$ latitude and $71^{\circ} 97$ to $72^{\circ} 15 \mathrm{E}$ longitude. The area is bounded by Mardan \& Charsadda on Northern side, Peshawar district on East side, Swabi district on north east and Kohat district in south. Attock district is located to the southeast (Fig. 1). After proper collection samples were preserved and identified in newspaper for 2 weeks to get moisture free. For the
Cell has the ability to produce these oxidizing agents through the process of metabolism or these agents may be present in food, water and air. To maintain optimal physiological conditions, it is essential to maintain a homeostatic balance between antioxidant and oxidants. Disturbance in the balance state of these agents may lead to oxidative stress and severe infection. Protein, lipids and DNA can be damaged by excessive oxidative stress and leading to increased risk of cancer [23-25]. To encounter this risk or slow down the oxidative stress prompted by free radicals, consumption of sufficient antioxidant agents is required $[17,18]$. Antioxidant compounds in the form of phytochemicals (Phenolic and carotenoids) can be obtained from plant species which lower the risk of instability and provide protection from disease [26-29]. In the present work, detection of various metabolites were examined in selected medicinal plants from district Nowshera which are helpful for utilization of various therapies. preparation of extract the collected samples were crushed into a grainy powder and was extracted in solvents of polar and non-polar grade (Methanol, n-hexane and Chloroform) the obtained crude extract were evaporated through rotary evaporator to make them dry.

\section{Phytochemical analysis}

Various samples of plant extract were subjected to qualitative chemical analysis to test the occurrence of different phytochemical constituents in extract samples. The phytochemical constituents of plant extract were partitioned in methanolic crude extraction, $n$ - hexane and chloroform by means of standard techniques [30-32] after followed by [33-35] for the documentation of chemical ingredients. 


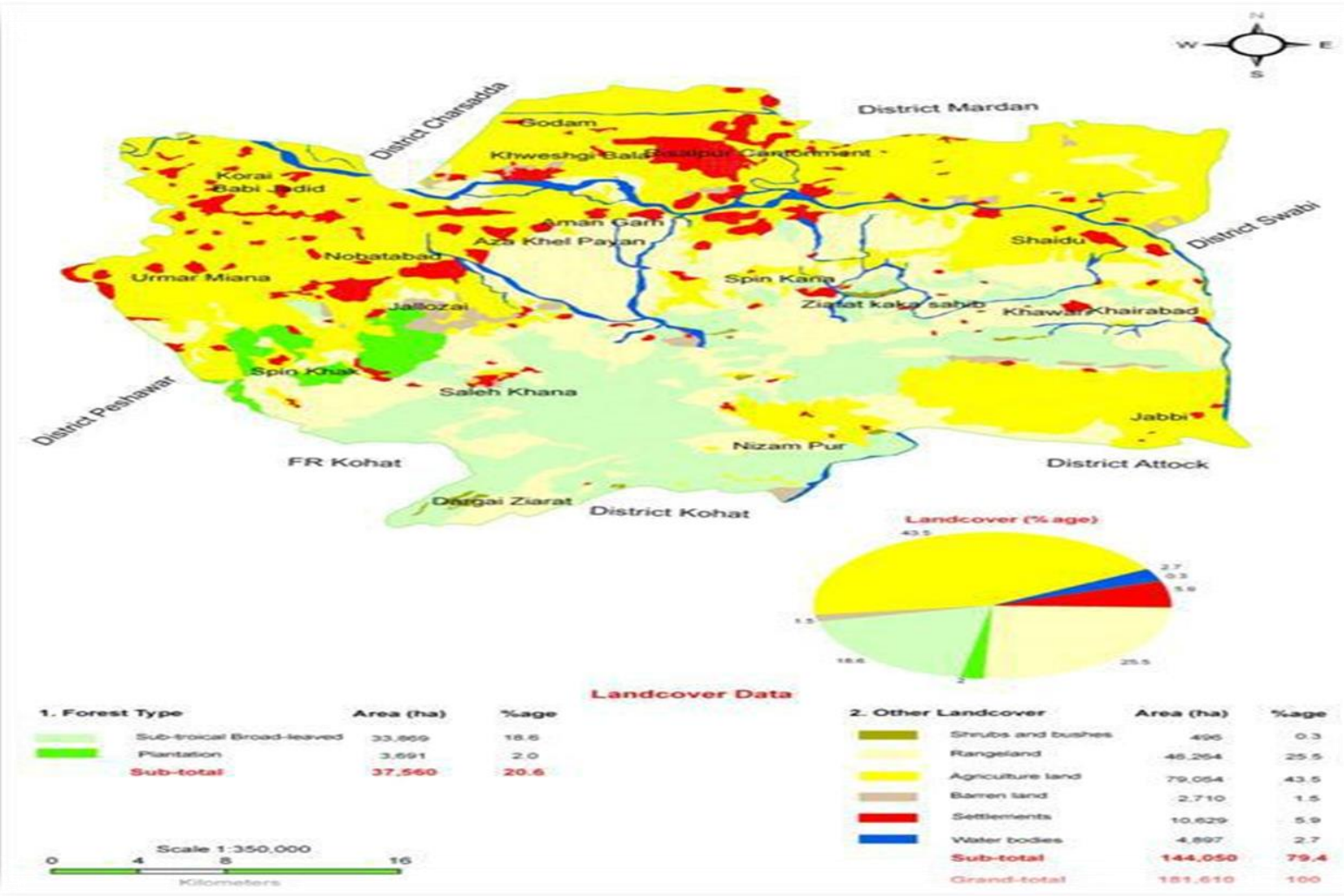

Figure 1. Map of the study area

\section{Test for alkaloids}

For the test of alkaloids content each portion (0.2g) was heated with $2 \%$ of $\mathrm{H}_{2} \mathrm{SO}_{4}(2.0 \mathrm{ml})$ for two minutes. The resulted mixture was then clean and filtered by sprayed a few drops of Dragendrof's mixture to filtrate. The indication of alkaloids in the sample extract shown by orange color.

\section{Test for tannins}

Each extract in small quantity was mixed with water and heated on water bath and filtered. To filtrate, few drops of $\mathrm{FeCl}_{3}$ and a dark green solution were obtained which show the occurrence of tannins.

Fehling's test or Test for reducing sugars For Fehling's test the sample extract and few drops of Fehling's solution (A \& B) in a test tube were heated with taster solution $(0.5 \mathrm{~g}$ sample in $5 \mathrm{ml}$ of $\mathrm{H}_{2} \mathrm{O}$ ). The presence of red precipitate indicates the sugars in the sample extract.

\section{Test for saponin contents}

For the test of saponin contents 0.5 gram of plant extract and $5 \mathrm{ml}$ of distilled water was added in a test tube. The reaction solution was the boiled and shak1es dynamically till the creation of a persistent froth. Olive oil of 3 drops was mixed in the frothing and was vigorously shaken till the formation of suspension, which shows the presence of saponins.

\section{Test for flavonoid contents}

For the screening of flavonoid contents dilute $\mathrm{NH}_{3}(5 \mathrm{ml})$ was mixed to a portion of aqueous filtrate of the extract. Then added a small amount of concentrated $\mathrm{H}_{2} \mathrm{SO}_{4}$ (1ml). A creamy yellow pigmentation that vanished on standing specified the occurrence of flavonoids

\section{Test for terpenoids}

$3 \mathrm{ml}$ of concentrated $\mathrm{H}_{2} \mathrm{SO}_{4}$ was added with $0.5 \mathrm{~g}$ in a test tube carefully each of the extract 
in $2 \mathrm{ml}$ of chloroform solution to form a reddish-brown pigmentation at the boundary which showed the occurrence of terpenoids.

Keller-Killiyani test (Test for cardiac glycosides)

$5 \mathrm{ml}$ of water was diluted with $0.5 \mathrm{~g}$ of extracts in a test tube. $2 \mathrm{ml}$ of glacial acetic acid with One drop of ferric chloride was added and then again this mixture was further drop wise take in the aqueous extract. This was minimized with $1 \mathrm{ml}$ of intense sulphuric acid. A brown ring at the boundary designated the occurrence of a deoxy sugar.

\section{Test for Total phenols}

Total phenolic secondary metabolites of selected sample were investigated by the technique of [36]. About $0.1 \mathrm{~mL}(0.5 \mathrm{mg} / \mathrm{mL})$ of extract sample was mixed with $2.8 \mathrm{~mL}$ of $10 \% \mathrm{Na}_{2} \mathrm{CO}_{3}$ and $0.1 \mathrm{~mL}$ of $2 \mathrm{~N}$ FolinCiocalteu reagents after a colored ring is formed which represents the presence of phenols.

\section{Test for anthraquinone contents}

$0.5 \mathrm{~g}$ of each sample extract was mixed and boiled with $10 \% \mathrm{HCl}$ solution for few minutes. The reaction mixture was then cleaned and permissible to cool. Equal volume of $\mathrm{CHCl}_{3}$ was mixed to filtrate along with few drops of $10 \% \mathrm{NH}_{3}$ and heated. Rose-pink color formation was found which indicates the presence of anthraquinone contents.

\section{Results and discussion}

Medicinal plants study is too much important to recognize the correct identification of crude drugs. For this determination, prominence is laid down on calibration of remedial plants used in health problems [37]. Pharmacognosy is mostly based on chemical, physical, biological and biochemical properties of crude drugs of wild origin as well as the exploration for new crude drugs from natural source [38]. It is a long recognized discipline in characterization, findings, standardization and manufacturing of plant materials in term of their anatomical, morphological and biochemical characteristics [39, 40]. Plants contain numerous bio-active ingredients of pharmacological significance [41]. In the current study qualitative phytochemical test of (10) particular plants (Chenopodium murale, Olea ferruginea, Plantago lanceolata, Parthenium hysterophorus, Lactuca serriola, Carthamus oxycantha, Achyranthes aspera, Chrozophora tinctoria, Cichorium intybus and Withania somnifera) was studied to standardized histologic and morphologic characteristics of these drugs. Alkaloids were detected and present in all botanical taxa in methanol and chloroform fraction while absent in $\mathrm{N}$-hexane fraction at vegetative stage using Dragon drof test (Table 1). Therefore primary phytochemical investigation is significant and valuable for separation of pharmacologically active complexes existing in these plants [42]. The anti-oxidant action of plant is due to the existence of compounds like secondary metabolites for example flavonoids, tannins, Terpenoids, saponins and phenolics $[33,35]$. The qualitative phytochemical screening were carried out by using methanol crude extract, chloroform extract and n-hexane extract for the whole plant two phenological stages (vegetative and fruiting stage)

\section{Alkaloids}

Alkaloids contain the basic element nitrogen so this is a type of secondary metabolite with acrid /bitter taste provides protection to the floras against to browsing and grazing. Majority of the alkaloid are therapeutically and physiologically active compound [38]. The phytochemical analysis of alkaloid at vegetative stage showed that alkaloid were existing in all selected taxon at chloroform and methanolic fraction although absent only in Achyranthes aspera and Chrozophora tinctoria in chloroform fraction (Table 1) while maximum in $\mathrm{n}$-hexane fraction except Cichorium intybus, Chenopodium murale, Lactuca serriola and Withania somnifera. At 
fruiting stage alkaloids were also observed in all botanical taxa in methanol and chloroform fraction but in N-hexane fraction alkaloids is present in some taxa (O. ferruginea, $P$. lanceolata, $P$. hysterophorus, $C$. oxycantha, $C$. tinctoria and $A$. aspera) while absent in $C$. murale, L. serriola, $W$. somnifera and $C$. intybus at fruiting stage (Table 2). Our result was sustained by [43] who worked on ten medicinal taxa and detected the presence of Alkaloids, tannins, saponins, steroid, terpenoid, flavonoids, phlobatannin and cardic glycoside in Nigerian medicinal plants while Naz \& Bano working on leaves of Lantana camara noted that at fruiting stage it has high concentrated Alkaloid, Phenolic and flavonoids which support our outcomes. Ethanol and Methanol extract revealed the occurrence of new secondary metabolites than other extracts [44].

\section{Tannins}

Tannins act as nourishing deterrents against gazers because they cause astringency. Occurrence of tannins secondary metabolites also proposes a major healing role in managements of some human illnesses [45]. At non reproductive stage the tannins were detected in all observed samples at methanol fraction while in chloroform fraction they were found in some plants except Achyranthes aspera and Withania somnifera. The n-hexane fraction shows its absence in all plants except Carthamus and Lactuca (Table 1). The present result was supported by [46] who stated that Methanolic and aqueous extract of Ficus infectoria contained more these medicinally important active secondary metabolites than other extracts. While at maturing period tannin existed in all plants at all portions (Table 2). [47] also supported our findings who described that the methanol extract of the foliage, root bark and stem bark of Securinega virosa have more phytochemical constituents than other extracts. [48] also described that Ethyl acetate produced the maximum class of these phytochemicals than the n-hexane and aqueous extracts of Euphorbia milli. Our findings also supported by [49] while working on Skimmia laureola and stated that flavonoids, alkaloids and tannins were noticed in aqueous and ethanol extract but absent in n-hexane fraction. Similarly [50] also described the phytochemical constituents of leaf of Hygrophila spinosa and reported the maximum quantity of secondary metabolite in methanol fraction.

\section{Sugar}

The preliminary screening of selected plants in chloroform, methanol and n-hexane fraction investigated that methanol fraction bear the sugar in all plants although in the nHexane fraction no plants show the presence of sugar at vegetative phase (Table 1). The work was in contradiction to [49] who reported that qualitative phytochemical detection of the leaves of Skimma laureola showed that starches were present in all ethanol aqueous and n-Hexane extract in the leaves. In chloroform portion the Chenopodium, Carthamus and Parthenium show its present while in rest of the plants they are not found. At fruiting stage they were originate in all plants at methanolic fraction (Table 2). In chloroform fraction they were screened out from the Plantago, Achyranthes, Withania and Cichorium while in n-hexane fraction they were screened out in all plants material. Ethyl alcohol extract show greater activity than the n-hexane and chloroform [48].

\section{Saponins}

Saponins are important type of glycosides with soapy features has showed to be an important antifungal agents [51, 52]. The phytochemical analysis reveals that saponins were present in all plants except Chrozophora in both methanol and in chloroform portion while the n-hexane fraction showed that saponins were found only in three plants (Parthenium, Chenopodium and Plantago) and absent in 
the rest of the plants at vegetative phase (Table 1). The saponins at fruiting stage gives the same result (as it was in vegetative stage) at the methanol and chloroform fraction while in n-hexane fraction $50 \%$ (Chenopodium, Olea, Lactuca, Carthamus and Parthenium) of plant show presence and $50 \%$ (Plantago, Withania, Chrozophora, Achyranthes, and Cichorium) plant shows absence. In Olea ferruginea the saponins detection proved to be very strong positive result as compared to others (Table 2). The Qualitative phytochemical investigation was studied using different extract of whole plants at post reproductive and vegetative phase. [53] reported that flavonoids and other phenolics compounds in native plants were in higher concentration than the exotic species. Similarly [54] studied the primary phytochemical screening of Scutellaria bacalensis and described the maximum amount of secondary metabolites in methanol fraction.

\section{Flavonoids}

Flavonoids in plants prevent oxidative cell injury. It is also possess anticancer, antiseptic and anti-inflammatory properties and mild oversensitive things [55]. Similarly Havsteen (2002) described some stimulating biotic actions of flavonoids like antioxidant, antimicrobial, cardio protective anti-viral, and neuroprotective properties. Flavonoids also present in the leaves of many members of family Euphorbiaceae which help in prevention from oxidative cell injury [55]. The phytochemical investigation for flavonoid in vegetative phase presented its occurrence in all plants at methanol and chloroform sections but in n-Hexane fraction they were absent in all selected plants (Table 1). At fruiting stage the flavonoids were present in methanol and chloroform fraction, while in n-hexane they were also found in some plants except Chenopodium, Plantago, Chrozophora and Cichorium (Table 2). Olea ferruginea and Carthamus oxycantha in methanol fraction shows strong positive result while in chloroform fraction only Olea ferruginea shows strong positive results at fruiting stage. The presence and absence of flavonoids were also depends on the area from where the plant material was collected [56] and clarify the detection of flavonoids content which is less in Chenopodium album than the Solanum nigrum. Similarly [57] exposed ethanol extract of Clitoria ternatea seed to primary phytochemical examinations and found the maximum of chemicals in it.

\section{Terpenoids}

Terpenoids are secondary metabolites due to which the plants show the antibacterial and antifungal activities [33, 35]. Some terpenes like gibberellins (Diterpenes) have basic role in development and growth of plant body. At vegetative phase the results for terpenoids showed its presence in all plants at methanolic fraction, while the tests chloroform and n-hexane fraction show its presence in maximum plants in both fraction but in Plantago, Carthamus and Achyranthes it was absent in both fraction using Salkowiski test. Highest terpenoids composition observed only in $\mathrm{N}$-hexane fraction in Parthenium hysterophorus at vegetative stage (Table 1). The terpenoid compounds at ripening phase presented its occurrence in all plants at methanol and chloroform fractions, while the results for nHexane designates its occurrence in plants except Parthenium and Plantago. Maximum terpenoids content observed in all fraction in Olea ferruginea at fruiting stage (Table 2). Our result were supported by [58] who investigated that among the different fractions ethyl acetate and methanol showed the high concentration of tannin, phenolics and sugar contents and less components were found in n-hexane fraction. This investigation was in opposing to [49] while working with Skimmia laureola and reported that Triterphenoids, Phytosterol, volatile oil 
and fixed oil were partitioned out in the Ethanolic fraction.

\section{Cardiac glycosides}

These are nitrogen containing secondary metabolites of plants, which emits toxins or volatile poisons when the plants are crumpled. The toxins or these volatile poisons so unconfined are nourishing deterrents for majority of insect and for Herbivores. The results at vegetative phase exposes that cardiac glycosides was establish in plants except Withania and Carthamus in both Methanol and chloroform fractions similarly the tests for $n$-hexane indicate that it was found only in Olea, Plantago and Cichorium, while absent in the rest of all plants at vegetative phase (Table 1). At fruiting stage it was found in all plants at methanolic and n-hexane fraction, while in the n-hexane fraction it is absent in Chenopodium, Plantago, Parthenium and Achyranthes while found in the rest of the plants. Plants at maturity stage (fruiting) showed higher affinity in methanol fraction in Olea ferruginea and Chrozophora tinctoria while in chloroform fraction only Olea ferruginea shows high affinity (Table 2). Our results were sustained by [59] who described less quantity of secondary metabolites was presented in n-Hexane than methanolic fraction.

\section{Phenolics}

Phenolics are aromatic compound and are synthesized in plants either from acetyl-CoA or from erythrose-4-phosphate. Phenolics compounds are responsible for antioxidant activity [60]. Phenolic compounds play a significant role in plants in attracting pollinators, fruits and seeds dispersers. Phenolics also play an important role in allelopathy. The tests for phenolic at vegetative phase reveals that they were originate in all plants at methanolic fraction, while in chloroform fraction they were only absent in one plant Achyranthes similarly results regarding n-hexane showed that phenolic were absent in all plants except Parthenium and Chrozophora (Table 1). The fruiting stage indicated that phenolics were found in all plants at all three fractions respectively (Table 2). [56] also give suggestion regarding phenolics which were less in Chenopodium album than the Solanum nigrum during fruiting stage which is against to our result.

\section{Anthraquinones}

At non-reproductive period in methanol fraction it was establish in $50 \%$ of plants (Withania, Chenopodium, Carthamus, Parthenium and Chrozophora) and partitioned out in rest of $50 \%$ of plants (Cichorium, Olea, Lactuca, Plantago and Achyranthes). In chloroform section it was only established in Chrozophora while in nHexane fraction it was absent in all botanical taxa (Table 1). [61] also described the fewer extents of the secondary metabolites in Methanol than n-Hexane, which maintenance our outcomes. At fruiting stage in chloroform and methanolic fraction the tests exposes that it remained only lacking in Cichorium and position in rest of plants (Table 2). The nhexane fraction showed that it was screened out in Olea, Achyranthus, Withania and Cichorium while found in the rest of plants. [56] reported that the Amaranthus dubius has more secondary metabolites contents than Chenopodium album, Solanum nigrum and Urtica lobulata. Patra [62] investigated the ethanolic fraction and detected the presence of anthraquinone, alkaloids, tannins, steroids, flavonoids, proteins, mucilage, fats, organic acids and oils in the leaves of Hygrophila spinosa. The present work recommends that primary phytochemical analysis is of the most important for separation of active ingredients from plant constituents and the current work is in agreement with the work of these researchers. 
Table 1. Detection of different phytoconstituents at vegetative stage occurring in district Nowshera

\begin{tabular}{|c|c|c|c|c|c|c|c|c|c|c|c|c|c|c|c|c|c|c|c|c|c|c|c|c|c|c|c|c|c|c|c|}
\hline \multirow{2}{*}{$\begin{array}{l}\text { Secondary } \\
\text { metabolites }\end{array}$} & \multicolumn{10}{|c|}{ Methanol fraction } & \multicolumn{10}{|c|}{ Chloroform fraction } & \multicolumn{10}{|c|}{ N-Hexane fraction } & \multirow{2}{*}{ Test Name } \\
\hline & 1 & 2 & 3 & 4 & 5 & 6 & 7 & 8 & 9 & 10 & 1 & 2 & 3 & 4 & 5 & 6 & 7 & 8 & 9 & 10 & 1 & 2 & 3 & 4 & 5 & 6 & 7 & 8 & 9 & 10 & \\
\hline Alkaloids & + & + & + & + & + & + & + & + & + & + & + & + & + & + & + & + & - & - & + & + & - & - & - & - & - & - & - & - & - & - & Dragondrof \\
\hline Tannins & + & + & + & + & + & ++ & + & + & + & + & + & + & + & + & + & + & + & - & - & + & - & - & - & + & - & + & - & - & - & - & $\begin{array}{c}\text { Ferric } \\
\text { chloride } \\
\text { test }\end{array}$ \\
\hline Sugar & + & + & + & + & + & + & + & + & + & + & - & + & - & - & + & + & - & - & - & - & - & - & - & - & - & - & - & - & - & - & Fehling test \\
\hline Saponins & + & + & + & + & + & + & - & + & + & + & + & + & + & + & + & $t$ & - & + & + & + & - & + & + & - & + & - & - & - & - & - & $\begin{array}{l}\text { Frothing } \\
\text { test }\end{array}$ \\
\hline Flavonoids & + & + & + & + & + & + & + & + & + & + & + & + & + & + & + & + & + & + & + & + & - & - & - & - & - & - & - & - & - & - & $\begin{array}{c}\text { Alkali } \\
\text { reagent }\end{array}$ \\
\hline Terpenoids & + & + & + & + & + & + & + & + & + & + & + & + & - & + & + & - & + & - & + & + & + & + & - & + & ++ & - & + & - & + & + & Salkowiski \\
\hline $\begin{array}{c}\text { Cardiac } \\
\text { Glycosides }\end{array}$ & + & + & + & + & + & - & + & + & - & + & + & + & + & + & + & - & + & + & - & + & + & - & + & - & - & - & - & - & - & + & $\begin{array}{l}\text { Killaer } \\
\text { killani }\end{array}$ \\
\hline Phenolics & + & + & + & + & + & + & + & + & + & + & + & + & + & + & + & $t$ & + & - & + & + & - & - & - & - & + & - & + & - & - & - & $\begin{array}{c}\text { Ferric } \\
\text { chloride }\end{array}$ \\
\hline Anthraquinone & - & + & - & - & + & + & + & - & + & - & - & - & - & - & - & - & + & - & - & - & - & - & - & - & - & - & - & - & - & - & $\begin{array}{c}\mathrm{HCl} \\
\text { detection } \\
\text { test }\end{array}$ \\
\hline
\end{tabular}


Table 2. Detection of different phytoconstituents at fruiting stage occurring in district Nowshera

\begin{tabular}{|c|c|c|c|c|c|c|c|c|c|c|c|c|c|c|c|c|c|c|c|c|c|c|c|c|c|c|c|c|c|c|c|}
\hline \multirow{2}{*}{$\begin{array}{l}\text { Secondary } \\
\text { metabolites }\end{array}$} & \multicolumn{10}{|c|}{ Methanol fraction } & \multicolumn{10}{|c|}{ Chloroform fraction } & \multicolumn{10}{|c|}{ N-Hexane fraction } & \multirow{2}{*}{ Test Name } \\
\hline & 1 & 2 & 3 & 4 & 5 & 6 & 7 & 8 & 9 & 10 & 1 & 2 & 3 & 4 & 5 & 6 & 7 & 8 & 9 & 10 & 1 & 2 & 3 & 4 & 5 & 6 & 7 & 8 & 9 & 10 & \\
\hline Alkaloids & + & + & + & + & ++ & ++ & ++ & + & + & + & + & + & + & + & + & + & + & + & + & + & + & - & + & - & + & + & + & + & - & - & Dragon drof \\
\hline Tannins & + & + & + & ++ & + & + & + & + & + & + & + & + & + & + & + & + & + & + & + & + & + & + & + & + & + & + & + & + & + & + & $\begin{array}{c}\text { Ferric } \\
\text { chloride test }\end{array}$ \\
\hline Sugar & + & + & + & ++ & + & + & + & + & + & + & + & + & - & + & + & + & + & - & - & - & - & - & - & - & - & - & - & - & - & - & Fehling test \\
\hline Saponins & ++ & + & + & + & + & + & - & + & + & + & + & + & + & + & + & + & - & + & + & + & + & + & - & + & + & + & - & - & - & - & Frothing test \\
\hline Flavonoids & ++ & + & + & + & + & ++ & + & + & + & + & ++ & + & + & + & + & + & + & + & + & + & + & - & - & + & + & + & - & + & + & - & $\begin{array}{c}\text { Alkali } \\
\text { reagent }\end{array}$ \\
\hline Terpenoids & ++ & + & + & + & + & + & + & + & + & + & ++ & + & + & + & + & + & + & + & + & + & ++ & + & - & + & - & + & + & + & + & + & Salkowiski \\
\hline $\begin{array}{c}\text { Cardiac } \\
\text { Glycosides }\end{array}$ & ++ & + & + & + & + & + & ++ & + & + & + & ++ & + & + & + & + & + & + & + & + & + & + & - & - & + & - & + & + & - & + & + & Killaerkillani \\
\hline Phenolics & ++ & + & + & ++ & + & + & + & + & + & + & ++ & + & + & + & + & + & + & + & + & + & + & + & + & + & + & + & + & + & + & + & $\begin{array}{c}\text { Ferric } \\
\text { chloride }\end{array}$ \\
\hline Anthraquinone & + & + & + & + & + & + & + & + & + & - & + & + & + & + & + & + & + & + & + & - & - & + & + & + & + & + & + & - & - & - & $\begin{array}{c}\mathrm{HCl} \\
\text { detection test }\end{array}$ \\
\hline
\end{tabular}

Keys: 1= Olea ferruginea Royle. 2= Chenopodium murale L. 3= Plantago lanceolata L. 4= Lactuca serriola L. 5= Parthenium hysterophorus L. 6= Carthamus oxycantha M. Bieb. 7= Chrozophora tinctoria (L.) Raf. 8= Achyranthes aspera L. 9= Withania somnifera (L.) Dunal. 10= Cichorium intybus L. 


\section{Conclusion}

The results of phytochemical screening of the selected plants showed that medicinal plants significance is due to the occurrence of many secondary metabolites. These are biologically active components. The methanol soluble fraction contained most of these biologically active substances, while nhexane fraction showed the least of these compounds. It was concluded that chloroform and methanolic plant extract is suitable for identification and authentication of medicinal plants because in these fraction all botanical taxa show strong positive results.

\section{Authors' contributions}

Conceived and designed the experiments: $S$ Ali, Performed the experiments: S Ali \& MN Khan, Analyzed the data: MN Khan, K Ali \& M Iqbal, Contributed materials/ analysis/ tools: K Ali, S Ali \& A Zaman, Wrote the paper: S Ali \& MN Khan.

\section{References}

1. Harborne JB (2011). Phytochemical methods: A guide to modern techniques of plant analysis, Springer International 3rd edition 1.

2. Yadav RNS \& Agarwala M (2011). Phytochemical analysis of some medicinal plants. J of Phytol 3(12): 10-14.

3. Solomon $\mathrm{CU}$, Arukweuche I \& Ifeanyi O (2013). Preliminary phytochemical screening of different solvent extracts of stembark and roots of Dennetia tripetala G. Baker. Asian J Plant Sci Res 3(3): 10-13.

4. Sawada Y, Nakabayashi R, Yamada Y, Suzuki M, Sato M, Sakata A, Akiyama K, Sakurai T, Matsuda F, Aoki T \& Hirai MY (2012) . RIKEN tandem mass spectral database (ReSpect) for phytochemicals: a plant-specific MS/MS-based data resource and database. Phytochem 82: 38-45.

5. Kennedy DO \& Wightman EL (2011). Herbal extracts and phytochemicals: plant secondary metabolites and the enhancement of human brain function. Advances in Nutrition 2(1): 32-50.
6. Pimentel D \& Andow DA (1984). Pest management and pesticide impacts. Int J Tro Ins Sci 5(3): 141-149.

7. Reymond P, Weber H, Damond M \& Farmer EE (2000). Differential gene expression in response to mechanical wounding and insect feeding in Arabidopsis. The Plant Cell 12(5): 707-719.

8. Hermsmeier D, Schittko U \& Baldwin IT (2001). Molecular interactions between the specialist herbivore Manduca sexta (Lepidoptera, Sphingidae) and its natural host Nicotiana attenuata. I. Large-scale changes in the accumulation of growth-and defense-related plant mRNAs. Plant Physiol 125(2): 683-700.

9. Cooper-Driver GA (2001) Contributions of Jeffrey Harborne and co-workers to the study of anthocyanins. Phytochemistry 56(3): 229-236.

10. Gershenzon J (2017). The cost of plant chemical defense against herbivory: a biochemical perspective. In Insect-Plant Interactions (1993): 121-190 CRC Press.

11. Tahara $S$ (2007). A journey of twenty-five years through the ecological biochemistry of flavonoids. Bioscience, biotechnology, and biochemistry 71(6): 1387-1404.

12. Wink M (2003). Evolution of secondary metabolites from an ecological and molecular phylogenetic perspective. Phytochemistry 64(1): 3-19.

13. Harborne JR (1993). Introduction to ecological biochemistry. Elsevier 4th ed. London.

14. Halberstein RA (2005). Medicinal plants: historical and cross-cultural usage patterns. Annals of epidemiology 15(9): 686-699.

15. Adimoelja A (2000). Phytochemicals and the breakthrough of traditional herbs in the management of sexual dysfunctions. Int $J$ And 23(S2): 82-84.

16. Liu RH (2003). Health benefits of fruit and vegetables are from additive and synergistic combinations of phytochemicals. The American journal of clinical nutrition 78(3): 517S-520S.

17. Chu YF, Sun JIE, Wu X\& Liu RH (2002). Antioxidant and anti-proliferative activities of common vegetables. J Agri Food Che 50(23): 6910-6916. 
18. Sun J, Chu YF, Wu X \& Li RH (2002). Antioxidant and anti-proliferative activities of common fruits. J Agri Food Che 50(25): 7449-7454.

19. Hollman PCH \& Arts ICW (2000). Flavonols, flavones and flavanols-nature, occurrence and dietary burden. J Sci Food \& Agri 80(7): 1081-1093.

20. Hollman PH \& Katan MB (1999). Dietary flavonoids: intake, health effects and bioavailability. Food and chemical toxicology 37(9-10): 937-942.

21. Kuhnau J (1976). Flavonoids. A class of semi-essential food components: Their role in human nutrition. World review of nutrition and dietetics.

22. Britton G (1995). Structure and properties of carotenoids in relation to function. The FASEB Journal 9(15): 1551-1558.

23. Liu RH \& Hotchkiss JH (1995). Potential genotoxicity of chronically elevated nitric oxide: a review. Mut Res/Rev in Gen Tox 339(2): 73-89.

24. Ames BN \& Gold LS (1991). Endogenous mutagens and the causes of aging and cancer. Mutation Research/Fundamental and Molecular Mechanisms of Mutagenesis 250(1-2): 3-16.

25. Ames BN, Shigenaga MK, \& Gold LS (1993). DNA lesions, inducible DNA repair, and cell division: three key factors in mutagenesis and carcinogenesis. Environmental health perspectives 101(S-5): 35-44.

26. Adom KK, \& Liu RH (2002). Antioxidant activity of grains. J Agr \&Food Che 50(21): 6182-6187.

27. Adom KK, Sorrells ME \& Liu RH (2003). Phytochemical profiles and antioxidant activity of wheat varieties. J Agr \&Food Che 51(26): 7825-7834.

28. Vinson JA, Su X, Zubik L \& Bose P (2001). Phenol antioxidant quantity and quality in foods: fruits. J Agr \& Food Che 49(11): 5315-5321.

29. Wang H, Cao G \& Prior RL (1996). Total antioxidant capacity of fruits. $J \mathrm{Agr} \& \mathrm{Food}$ Che 44(3): 701-705.

30. Trease GE \& Evans WC (1989) Pharmacogonosy. $13^{\text {th }}$ Edition. Bailliere Tindall 176-180.
31. Sofowara A (1993). Medicinal plants and traditional medicine in Africa. Spectrum books, Ibadan 150 .

32. Ayoola GA, Coker HA, Adesegun SA, Adepoju-Bello AA, Obaweya K, Ezennia EC, \& Atangbayila TO (2008). Phytochemical screening and antioxidant activities of some selected medicinal plants used for malaria therapy in Southwestern Nigeria. Trop. J. Pharm. Res 7(3): 10191024.

33. Uddin G, Rauf A, Qaisar M, Latif A \& Ali M (2011) Preliminary phytochemical screening and antimicrobial activity of Hedera halix L. Middle-East J. Sci. Res 8: 198.

34. Uddin G, Rauf A, Arfan M, Ali M,Qaisar M, Saadiq M \& Atif M (2012). Preliminary phytochemical screening and antoxidant activity of Bergenia caliata. Middle-East $J$. Sci. Res 11: 1140.

35. Rauf A, Qaisar M, Uddin G, Akhtar S, Muhammad N \& Qaisar M. (2012). Preliminary Antinociceptive studies of methanol extract of Euphorbia milli MiddleEast J Med. Plants Res 1: 09-13.

36. Makkar HPS, Bluemmel M, Borowy NK \& Becker K (1993). Gravimetric determination of tannins and their correlation with chemical and protein precipitation methods J. Sci. Food Agric 61: 161.

37. Najafi S \& Deokule SS (2010). Pharmacognostic study of Tylophora dalzellii Hook. f. J Med Plant Res 4(5): 403406.

38. Tyler VE (1999). Phytomedicines: back to the future J. Nat. Prod 62(11): 1589-1592.

39. Kalyan BV, Kothandam H, Palaniyappan V, \& Praveen AR (2011). Hypoglycaemic activity of seed extract of Clitoria ternatea Linn. in Streptozotocin- Induc Ed Diabetic Rats. Pharmacon. J 3(19): 45-48.

40. Kinghorn AD (2002). The role of pharmacognosy in modern medicine. Expert opinion on pharmacotherapy 3(2): 77-79.

41. Ming DS, Hillhouse BJ, Guns ES, AEberding, Xie S, Vimalanathan $\mathrm{S} \&$ Towers GHN (2005). For bioactive compounds from Rhodiola rosea 
(Crassulaceae) Phytotherapy Res 19 (9): 740-743.

42. Sugumaran M \& Vetrichelvan T (2008). Studies on some Pharmacognostic Profiles of Bauhinia purpurea Linn. Leaves (Caesalpinaceae). Ethnobotanical Leaflets 12: 461-468.

43. Edeoga HO, Okwu DE \& Mbaebie BO (2005). Phytochemical constituents of some Nigerian medicinal plants. African journal of biotechnology 4(7): 685-688.

44. Naz R \& Bano A (2013). Phytochemical screening, antioxidants and antimicrobial potential of Lantana camara in different solvents. Asi Pac J Tro Dis 3(6): 480-486.

45. Asquith TN \& Butler LG (1986). Interactions of condensed tannins with selected proteins. Phytochemistry 25(7): 1591-1593.

46. Urmila GH, Rao BG \& Satyanarayana $\mathrm{T}$ (2013). Physicochemical and preliminary phytochemical screening for medicinal plants. Int. J. Phar. Che. Sci 2(4).

47. Magaji M, Yaro GA, Mohammed, Zezi AU, Tanko Y \& Bala TY (2007). Preliminary antidiarrhoeal activity of methanolic extracts of Securinega virosa (Euphorbiaceae). Afr. J. Biotech 6(24): 2752-2757.

48. Rauf, Khan A, Uddin N, Akram M, Arfan M, Uddin G \& Qaisar M (2014). Preliminary phytochemical screening, antimicrobial and antioxidant activities of Euphorbia milli. Pak. J. Pharm. Sci 27(4): 947-951.

49. Ullah B, Ibrar M \& Muhammad N (2011). Evaluation of Skimmia laureola DC for invitro and in-vivo pharmacological screening. Afr. J. Pharm. \& Pharmacol 5(14): 1718-1723.

50. Arjun P, \& Shivesh J (2009). Pharmacognostical standardization of leaves of Hygrophila spinosa $T$. anders. Pharmacognosy Journal 1(2): 82.

51. Sodipo OA, Akanji MA, Kolawole FB \& Odutuga AA (1991). Saponin is the active antifungal principle in Garcinia kola heckles seed. Biosci. Res. Commun 3: 171.

52. Fluck H (1973). Medicinal plants and their uses, W. Feulsham and Comp Ltd, New York. 7-15.
53. Nijveldt RJ, Van Nood ELS, Van Hoorn DE, Boelens PG, Van Norren K, \& Van Leeuwen PA (2001). Flavonoids: a review of probable mechanisms of action and potential applications. The American journal of clinical nutrition 74(4): 418-425.

54. Chirikova NK, Olennikov DN \& Tankhaeva LM (2010). Pharmacognostic study of aerial parts of Baikal skullcap (Scutellaria baicalensis Georgi).Russian journal of bioorganic chemistry 36(7): 909-914.

55. Okwu DE \& Okwu ME (2004). Chemical composition of Spondias mombin Linn. plant parts. J Sustain Agric Environ 6(2): 140-147.

56. Kwinana-Mandindi $\mathrm{T}$ (2015). Phytochemical and antioxidant composition of selected local wild plants in South Africa: Consideration of alternative nutrients for health promotion. In 5th Intern Conference on Biomed Eng Tech 81(17): 96-102.

57. Kalyan BV, Kothandam H, Palaniyappan V \& Praveen AR (2011). Hypoglycaemic activity of seed extract of Clitoria ternatea Linn. in Streptozotocin-Induced diabetic Rats. Pharmacogn J 3(19): 45-47.

58. Skerget M, Kotnik P, Hadolin M, Hras AR, Simonic M \& Knez Z (2005). Phenols, proanthocyanidins, flavones and flavonols in some plant materials and their antioxidant activities. Food Chem 89(2): 191-198.

59. Hosseinian FS \& Beta T (2007). Saskatoon and wild blueberries have higher anthocyanin contents than other Manitoba berries. $J$ of Agric and Food Chem 55(26): 10832-10838.

60. Pietta PG (2000). Flavonoids as antioxidants. $J$ of Nat Prod 63(7): 10351042.

61. Gu Q, Lu J, Cui C, Zhu T, Fang Y, Liu H \& Zhu W (2004). Recent researches of bioactive metabolites in marine organismsassociated microorganisms. J of Ocean Uni of China 3(2): 150-156.

62. Patra A, Jha S \& Murthy PN (2009). Phytochemical and pharmacological potential of Hygrophila spinosa $T$. anders. Pharmacogn Rev 3(6): 330. 